\title{
Impact of warm ENSO events on atmospheric circulation and convection over the tropical Atlantic and West Africa
}

\author{
S. Janicot \\ Météo-France, Laboratoire de Météorologie Dynamique du CNRS, Palaiseau, France
}

Received: 20 June 1996 / Revised: 4 November 1996 / Accepted: 26 November 1996

\begin{abstract}
Empirical studies have shown that warm El Nino/Southern Oscillation (ENSO) episodes are associated during northern summer with, first, a southward location of the intertropical convergence zone (ITCZ) over the tropical Atlantic, and, second, a weakened convection over West Africa where the ITCZ is near its mean latitude. A modelling experiment presented here is used to help explain this apparent contradiction. In simulated ENSO conditions, the ITCZ is located southwards over the tropical Atlantic. Over West Africa the intertropical front is also displaced southwards, but more slightly; the ITCZ is located at its climatological latitude and the vertical development of convective clouds over West and Central Africa is reduced due to dynamical subsidence in the upper levels.
\end{abstract}

\section{Introduction}

West African rainfall variability has been connected to sea-surface temperature (SST) anomalies in the tropical Atlantic (Lamb, 1978a,b), but also in distant oceanic basins (Folland et al., 1986; Palmer, 1986). In particular, statistical associations have been investigated between Sahel rainfall and SST variability linked to El Nino/ Southern Oscillation (ENSO) events. Some studies have suggested that ENSO plays little or no role in West African precipitations (Stockenius, 1981; Nicholson, 1986; Ropelewsky and Halpert, 1987). In contrast, Ward (1992) and Palmer et al. (1992) pointed out the importance of ENSO forcing on interannual changes in Sahel rainfall. More recently, Rowell et al. (1995) demonstrated that correlations between West African rainfall and SST in the eastern equatorial Pacific are large at the interannual time-scale. Moron et al. (1995) and Janicot et al. (1996) also showed that this correlation has increased after 1970 in accordance with

$\overline{\text { (E-mail: janicot } @ 1 m d . e n s . f r) ~}$ stronger ENSO events and with an interdecadal evolution of the global SST field. Studies which found no ENSO - West Africa rainfall connection may have had the signal obscured by the large interdecadal variability displayed in the region (Palmer et al., 1992).

Hastenrath et al. (1987) computed the correlation pattern between the Southern Oscillation Index of Parker (1983) and the mean sea-level pressures in the tropical Atlantic and Pacific basins in the July-August periods 1935-1983 (Fig. 1a). Significant positive correlations appear over the eastern tropical Pacific (a positive Southern Oscillation Index is associated with a cold ENSO event) and negative correlations cover most of the tropical Atlantic with largest values in a band at $10^{\circ}-25^{\circ} \mathrm{N}$ extending from the coast of West Africa westwards into the open Atlantic. In accordance with the wind field correlation patterns (not shown), Hastenrath et al. (1987) concluded that during northern summer warm (cold) ENSO events are associated with a southward (northward) displacement of the intertropical convergence zone (ITCZ) over the tropical Atlantic.

On the other hand, Moron $(1993,1995)$ analysed statistical connections between ENSO events and African convection estimated through outgoing longwave radiation (OLR) records. In particular, he computed the warm (1976-79-82-83-87) minus cold (197581-84-85-88) ENSO composite of OLR anomaly fields over West Africa in July-August. This field (Fig. 2a) displays an overall decreasing convection over West and Central Africa, which is not consistent with a possible southward displacement of the ITCZ over the continent, as Hastenrath et al. (1987) observed over the tropical Atlantic. This apparent contradiction might be due to the different periods and parameters used by Hastenrath et al. and by Moron. A modelling experiment is presented here to investigate this point.

\section{Experimental design}

When performing statistical investigations on observational data sets, it is difficult clearly to differentiate the 

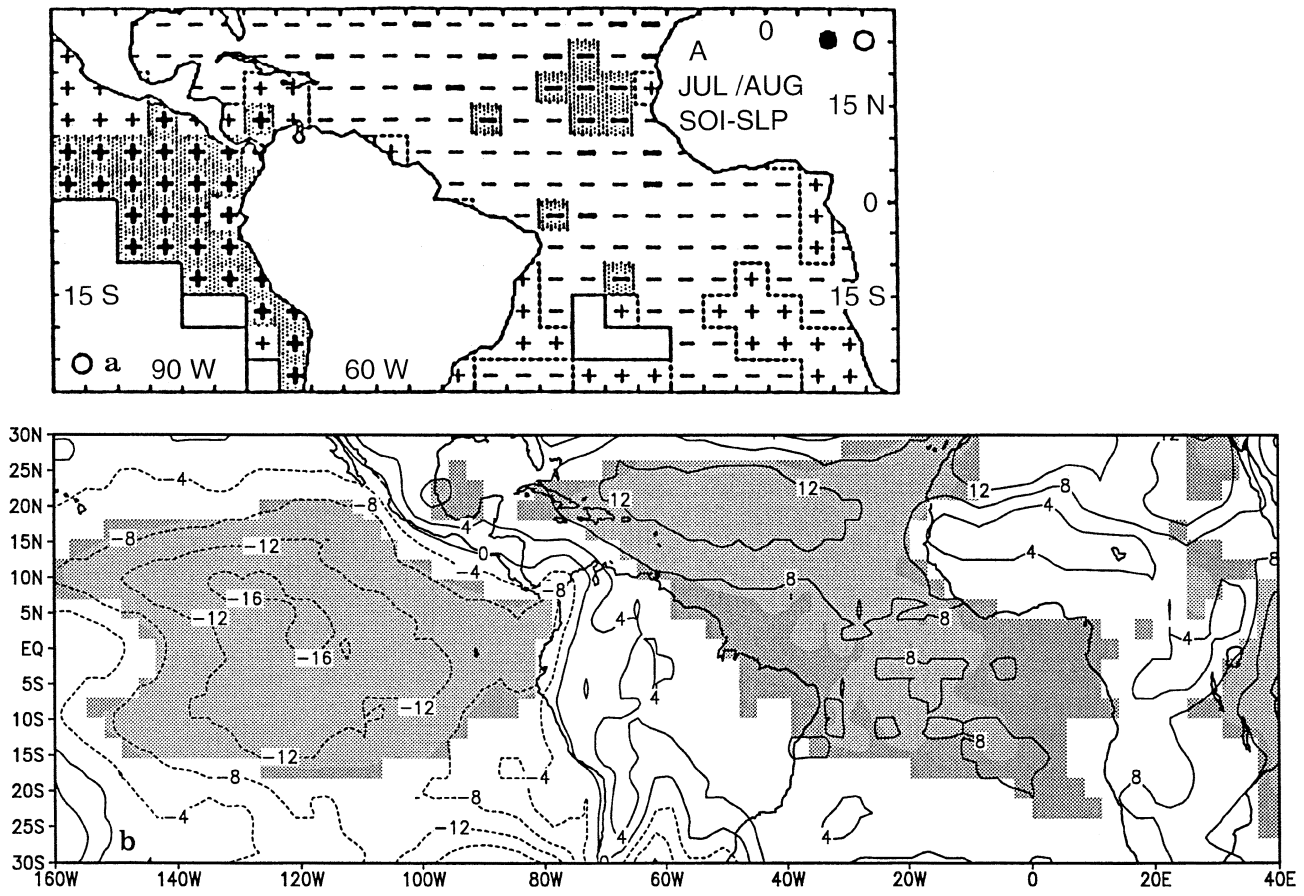

Fig. 1. a Pattern of correlations between the Southern Oscillation Index (Parker, 1983) and JulyAugust values of mean sea-level pressure during 1935-1983. Plus and minus denote the sign of the correlation, shading absolute values larger than 0.4 and bold-face type values with local significance at the $5 \%$ level. Blanks indicate areas with less than 20 years of data (Hastenrath et al., 1987). b Simulated mean sea-level pressure anomalies for the "ENSO" run relative to the control run. Isolines are in tenth of hPa every $0.4 \mathrm{hPa}$. Anomaly areas significant at the $5 \%(1 \%)$ level are shaded in dark (light) grey role of particular SST area since SST fields have large spatial common variability. The same problem arises with modelling experiments which involve general circulation models forced by global SST fields. The impact of positive equatorial SST anomalies located in the eastern Pacific on atmospheric circulation and convection over the tropical Atlantic and West Africa has been investigated with the climate version of the ARPEGE-Climat general circulation model version 1.1 developed by CNRM (Centre National de Recherches Météorologiques at Météo-France) in a triangular spectral T42 resolution (Déqué et al., 1994). This SST area (Fig. 3) corresponds to the zone of large correlations between SST and West African rainfall pointed out by Rowell et al. (1995) at the interannual time-scale.
Two runs have been performed with this model in perpetual August mode over a 165-day period. The control run has been realized with the monthly mean AMIP-SST field averaged over the period 1979-1988. In the second run, called hereafter "ENSO" run, the SST anomalies displayed in Fig. 3 have been superimposed to the mean SST field. The range of these anomalies is about 1.5 times those observed during the mature phase of the warm ENSO event in summer 1987. Following Pitcher et al. (1988), the first 30 days have been used for the model stabilization, then 30 days have been averaged, 5 days omitted, 30 days averaged, 5 days omitted, etc., to obtain an four-member ensemble of independent 30-day-averaged fields. Ensemble means and variances have been calculated for each experiment, and differen-
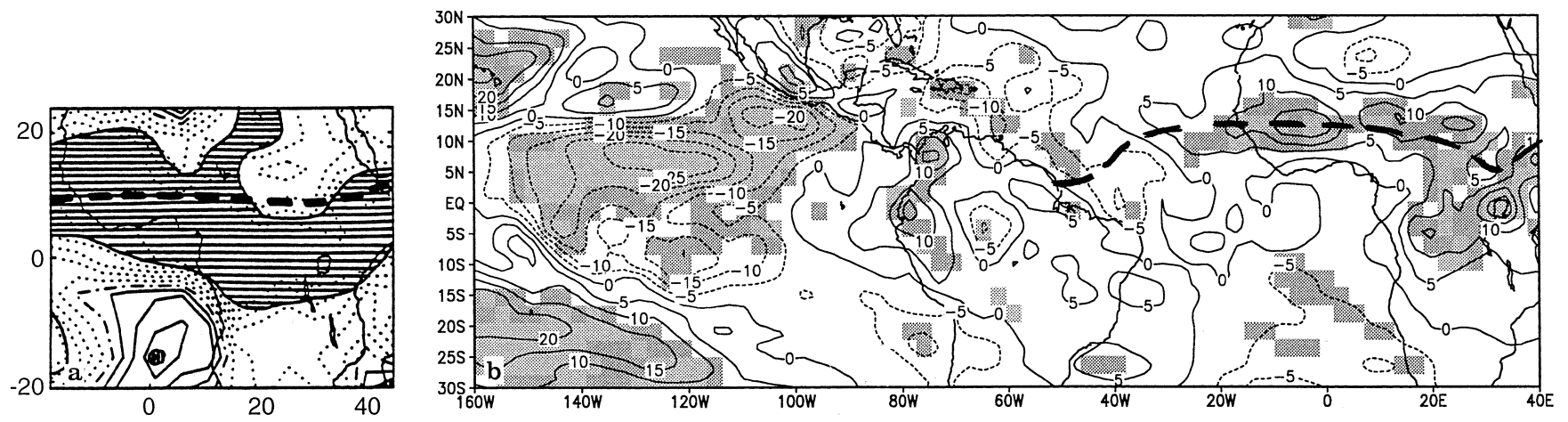

Fig. 2. a OLR differences observed in July-August between warm (1976-79-82-83-87) and cold (1975-81-84-85-88) ENSO events; positive values (dashed lines every 0.2 in standardized values) indicate weakened convection. The heavy dashed line indicates the location of the climatological minima of OLR (1974-1991). Hatched area represents the $t$-test values significant at the $10 \%$ level (Moron,
1993). b Simulated OLR anomalies for the "ENSO" run relative to the control run. Isolines every $5 \mathrm{Wm}^{-2}$; positive values (full lines) indicate weakened convection. The heavy dashed line indicates the location of the simulated climatological minima of OLR. Anomaly areas significant at the $5 \%(1 \%)$ level are shaded in dark (light) grey 


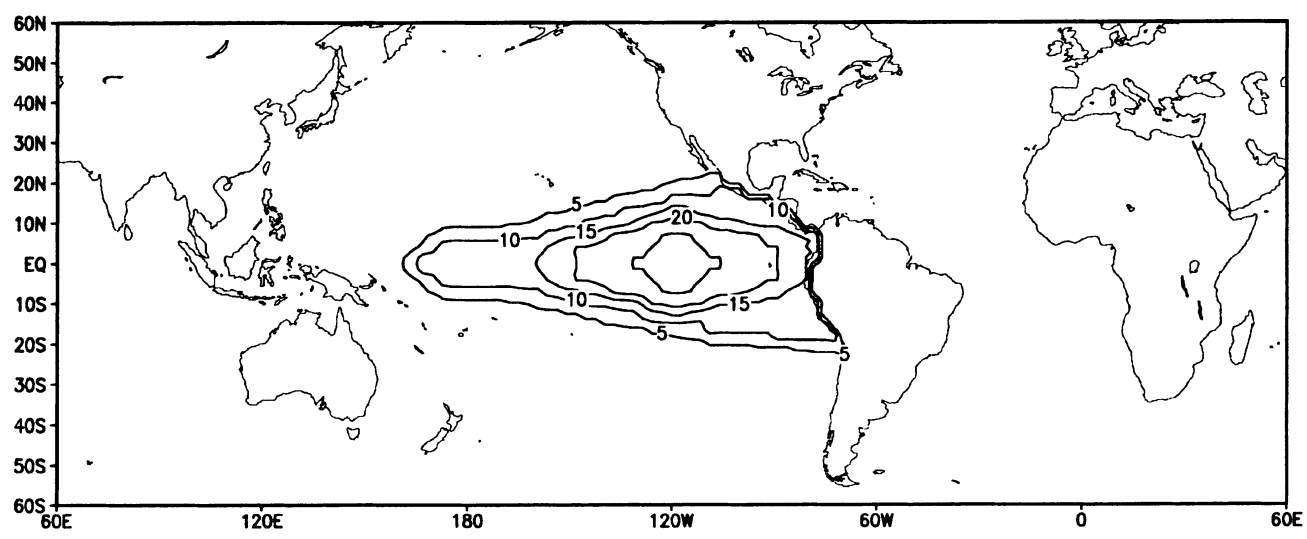

Fig. 3. SST anomalies used in the "ENSO" run. Isolines are in tenths of ${ }^{\circ} \mathrm{C}$ every $0.5^{\circ} \mathrm{C}$

ces of the means from the control run have been computed along with their local statistical significance by using a two-tailed $t$-test with $2(4-1)=6$ degrees of freedom. Hereafter differences between the "ENSO" run and the control run are presented and compared to the previous empirical results.

\section{Results}

Figure $1 \mathrm{~b}$ depicts the mean sea-level pressure anomalies for the "ENSO" run relative to the control run. These anomalies are significant at the $1 \%$ level over the tropical Pacific between $20^{\circ} \mathrm{N}$ and $15^{\circ} \mathrm{S}$ and over the tropical Atlantic between $25^{\circ} \mathrm{N}$ and $15^{\circ} \mathrm{S}$; they are not significant over West Africa. Considering the negative correlation between the Southern Oscillation Index and SSTs in the eastern Pacific, the pressure pattern of Fig. $1 b$ is very similar to the correlation pattern of Fig. 1a. In Fig. 1b a zonal dipole is pointed out between negative anomalies over the eastern tropical Pacific and positive anomalies over the whole tropical Atlantic. Second, higher positive pressure departures over the Atlantic along $15^{\circ} \mathrm{N}$ lead to a northward meridional pressure gradient along $10^{\circ} \mathrm{N}$. This is consistent with the simulated anomaly wind field at $900 \mathrm{hPa}$ (Fig. 4): west of $15^{\circ} \mathrm{W}$ along $10^{\circ} \mathrm{N}$ the north-easterly trade winds are enhanced, resulting from the positive Pacific SST anomalies which lead to a larger wind convergence in the eastern Pacific ITCZ located at $10^{\circ} \mathrm{N}$ in August. This wind enhancement over the tropical Atlantic leads to a southward displacement of the ITCZ (depicted by the peak of $900-\mathrm{hPa}$ wind convergence in Fig. 4) near the western coast of Africa. The resulting rainfall anomalies are significantly negative north of $10^{\circ} \mathrm{N}$ and weakly positive southwards (Fig. 5).

Figure 2b displays OLR anomalies for the "ENSO" run relative to the control run. The positive anomalies are significant at the $5 \%$ level along $10^{\circ} \mathrm{N}$ over West Africa and over Central Africa between $20^{\circ} \mathrm{E}$ and $40^{\circ} \mathrm{E}$. These anomalies are located on the climatological location of simulated OLR minima, meaning that the ITCZ is still at its mean latitude. This OLR pattern is very similar to the observed OLR composite pattern of the difference between ward and cold ENSO events (Fig. 2a). It describes under warm ENSO conditions a decreasing vertical development of convective clouds inside the African ITCZ. The heat source located over the eastern equatorial Pacific can force subsidence in the upper troposphere over West Africa. The geopotential height anomalies at $200 \mathrm{hPa}$ for the "ENSO" run relative to the control run are shown in Fig. 6. Positive anomalies are significant at the $1 \%$ level between $30^{\circ} \mathrm{N}$ and $30^{\circ} \mathrm{S}$. Over the SST area of Fig. 3, this pattern is baroclinic and corresponds to ascending motions. Elsewhere in the intertropical hand, the positive geopotential height anomalies exist in the whole troposphere (in particular over West Africa in the monsoon trough). Such a pattern has been observed by Horel and Wallace (1981) during warm ENSO events and has been described by Lim and Chang (1983) as a zonal barotropic mode. It is associated with a temperature increase in the upper troposphere and corresponds to subsiding motions linked to warm ENSO events (Barnett et al., 1991). It is consistent with a weakened convection over West and Central Africa. Note also that the positive sea-

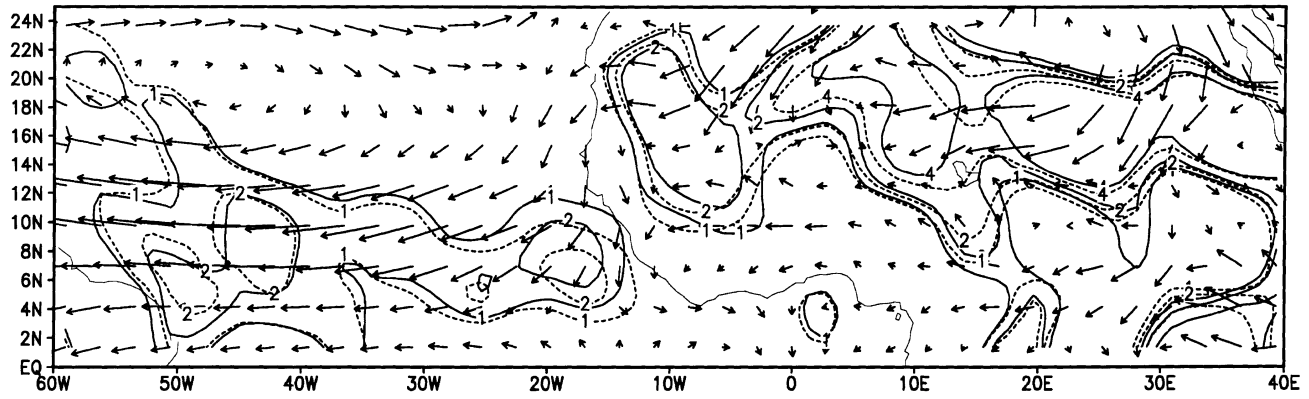

Fig. 4. Simulated $900-\mathrm{hPa}$ wind anomalies for the "ENSO" run relative to the control run. Vector length : $5^{\circ}$ longitude for $2 \mathrm{~ms}^{-1}$. Full (dashed) lines represent the 900-hPa wind convergence for the control ("ENSO") run. Isolines are in $10^{-6} \mathrm{~s}^{-1}$ 

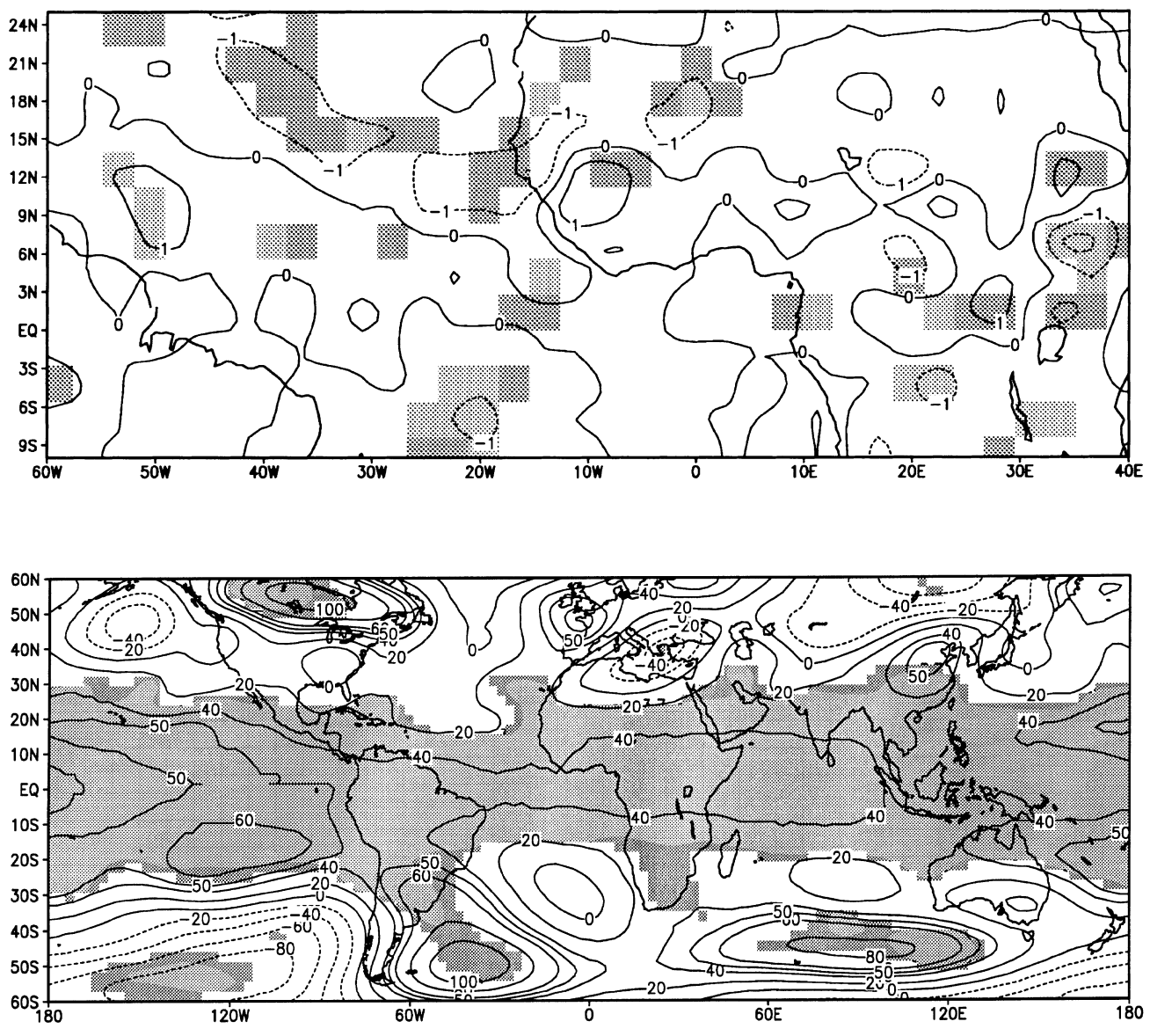

Fig. 5. Simulated rainfall anomalies for the "ENSO" run relative to the control run. Isolines are in $\mathrm{mm}$ day $^{-1}$. Anomaly areas significant at the $5 \%(1 \%)$ level are shaded in dark (light) grey

Fig. 6. Simulated 200-hPa geopotential height anomalies for the "ENSO" run relative to the control run. Isolines are in mgp every $20 \mathrm{mgp}$; the isolines $50 \mathrm{mgp}$ are also displayed. Anomaly areas significant at the $5 \%(1 \%)$ level are shaded in dark (light) grey level pressure anomalies over West Africa (Fig. 1b), though not significant are consistent with increased subsidence over the region during warm ENSO events. On the other hand, the dry north-easterly winds over West Africa are enhanced, leading to a slight equatorward displacement of the axis of $900-\mathrm{hPa}$ wind convergence (Fig. 4), in agreement with the weak northward meridional pressure gradient. This axis located between $15^{\circ} \mathrm{N}$ and $20^{\circ} \mathrm{N}$ characterizes the intertropical front, that is the line of surface convergence between the wet southwesterly monsoon and the dry north-easterly Harmattan. Consistently the resulting rainfall anomaly field over West Africa has significant negative anomalies north of $15^{\circ} \mathrm{N}$ and very localized significant positive ones southwards (Fig. 5). Statistically speaking, the signal associated to the weakened convection inside the African ITCZ (Fig. 2b) is larger than those linked to a southward retreat of the belt of rainfall maxima (Fig. 5).

\section{Conclusion}

Empirical studies have shown that warm ENSO events are accompanied during northern summer by a southward location of the ITCZ over the tropical Atlantic, and by a weakened convection over West and Central Africa where the ITCZ is at its climatological latitude. The ARPEGE-Climat general circulation model has been used to simulate the response to positive SST anomalies in the eastern equatorial Pacific whose pattern characterizes the mature phase of a warm ENSO episode. The two previous results have been largely confirmed and do not constitute a contradiction. The model simulates a southward displacement of the ITCZ on the tropical Atlantic resulting from the enhancement of north-easterly trade winds. Over West Africa, the intertropical front is also displaced southwards but more slightly; the ITCZ is still localized at its climatological latitude and the vertical development of convective clouds over West and Central Africa is reduced due to dynamical subsidence in the upper levels.

Acknowledgments. The author is grateful to the reviewers for their valuable comments.

Topical Editor L. Eymard thanks B. Fontaine and C. Landsea for their help in evaluating this paper.

\section{References}

Barnett, T. P., M. Latif, E. Kirk, and E. Roeckner, On ENSO physics, J. Clim., 4, 487-515, 1991.

Deque, M., C. Dreveton, A. Braun, and D. Cariolle, The ARPEGE/ IFS atmosphere model: a contribution to the French community climate modelling, Clim. Dyn. 10, 249-266, 1994.

Folland, C. K., T. N. Palmer, and D. E. Parker, Sahel rainfall and worldwide sea temperature 1901-1985, Nature, 320, 602-607, 1986. 
Hastenrath, S., L. C. De Castro, and P. Aceituno, The Southern Oscillation in the tropical Atlantic sector, Beitr. Phys. Atmos., 4, 447-463, 1987.

Horel J. D., and J. M. Wallace, Planetary-scale phenomena associated with the Southern Oscillation, Mon. Weather Rev., 109, 813-829, 1981.

Janicot, S., V. Moron, and B. Fontaine, Sahel droughts and ENSO dynamics, Geophys. Res. Lett., 23, 515-518, 1996.

Lamb, P. J., Case studies of tropical Atlantic surface circulation patterns during recent sub-Saharan weather anomalies: 1967 and 1968, Mon. Weather Rev., 106, 482-491, 1978 a.

Lamb, P. J., Large-scale tropical surface circulation patterns associated with sub-Saharan weather anomalies, Tellus, 30, 240-251, 1978b.

Lim, H., and C. P. Chang, Dynamics of teleconnections and Walker circulations forced by equatorial heating, J. Atmos. Sci., 40, 1897-1915, 1983.

Moron, V., Variabilité de la radiation OLR sur l'Afrique tropicale et relations avec la circulation de mousson Ouest-Africaine et les SST de l'Atlantique et du Pacique Est, Proc. $8^{\text {th }}$ Atelier de Modélisation', CNRM, Toulouse, France, 327-336, 1993.

Moron, V., Variability of the African convection centre as viewed by outgoing longwave radiation records and relationships with sea surface temperature patterns, Int. J. Climatol., 15, 25-34, 1995.

Moron, V., S. Bigot, and P. Roucou, Rainfall variability in subequatorial America and Africa and relationships with the main SST modes (1951-1990), Int. J. Climatol., 15, 1297-1322, 1995.
Nicholson, S. E., The quasi-periodic behavior of rainfall variability in Africa and its relationship to the Southern Oscillation, Arch. Meteorol Geophys. Bioklimatol., Ser.A, 34, 311-348, 1986.

Palmer, T. N., Influence of the Atlantic, Pacific, and Indian oceans on Sahel rainfall, Nature, 322,251-253,1986.

Palmer, T. N., C. Brankovic, P. Viterbo, and M. J. Miller, Modelling interannual variations of summer monsoons, $J$. Clim., 5, 399-417, 1992.

Parker, D. E., Documentation of a Southern Oscillation index, Meteorol. Mag., 112, 184-188, 1983.

Pitcher, E. J., M. L. Blackmon, G. T. Bates, and S. Munoz, The effect of north Pacific sea surface temperature anomalies on the January climate of a general circulation model, J. Atmos. Sci., 45, 173-188, 1988.

Ropelewsky, C. F., and M. S. Halpert, Global- and regional-scale precipitation and temperature patterns associated with El Nino/ Southern Oscillation, Mon. Weather Rev., 115, 1606-1626, 1987.

Rowell, D. P., C. K. Folland, K. Maskell, and M. N. Ward, Variability of summer rainfall over tropical North Africa (19061992): Observations and modelling, Q. J. R. Meteorol. Soc., 121, 669-704, 1995.

Stockenius, T., Interannual variations of tropical precipitation patterns, Mon. Weather Rev., 109, 1233-1247, 1981.

Ward, M. N., Provisionally corrected surface wind data, worldwide ocean-atmosphere surface fields, and Sahelian rainfall variability, J. Clim., 5, 454-475, 1992. 